\title{
Mídia e Política: a construção da agenda nas propostas de redução da maioridade penal na Câmara dos Deputados
}

\author{
Marcelo da Silveira Campos
}

Programa de Pós-Graduação em Ciência Política da

Universidade Estadual de Campinas

\begin{abstract}
Resumo: 0 artigo relaciona os processos e efeitos entre meios de comunicação de massa e a proposição de políticas públicas sobre o tema da redução da maioridade penal no Brasil. O objetivo é analisar como dois crimes de grande repercussão pública, ocorridos em 2003 e 2007, mobilizaram a tramitação das Propostas de Emenda à Constituição (PEC's) favoráveis à redução da maioridade penal na Câmara dos Deputados. O artigo analisa as matérias veiculadas pela Revista Veja e o Jornal Folha de S.Paulo nos períodos dos crimes com a hipótese de que tiveram impacto na apresentação de propostas favoráveis à redução da maioridade penal.
\end{abstract}

Palavras-chave: redução da maioridade penal; Câmara dos Deputados; proposta de emenda à Constituição; criminalidade.

\begin{abstract}
The article relates the processes and the effects among media vehicles and public policy propositions about the reduction of adult age penalty in Brazil. Based on the analysis of the newspaper Folha de São Paulo and the magazine Veja, it relates the repercussion of two crimes of great impact ocurred in 2003 and 2007 and their influence on the legislative processo of proposals of amendments to the Constitution.
\end{abstract}

Keywords: reduction of adult age penalty; House of Representatives; Constitution amendment proposal; crime. 


\section{Introdução ${ }^{1}$}

A relação entre a opinião pública ${ }^{2}$ e as políticas públicas é complexa, difusa e não linear em sociedades democráticas. Envolve uma multiplicidade de atores, ideias, interesses, instituições, demandas da sociedade civil de cada país (ou, ainda dentro de cada país, demandas de cada unidade federativa), que passam à margem de fáceis generalizações e simplificações tentadoras.

Scheufele \& Tewksbury (2007) relembram que nos EUA, em 1997, o republicano Frank Luntz, especialista em sondar a opinião pública, escreveu que o importante não é o que se diz, mas como se diz. Ou seja, os efeitos de determinadas mensagens não estão somente localizados na diferença de conteúdo, mas nas diferenças dos modos de apresentação destes conteúdos.

Tais ideias estão presentes nos conceitos de framing (GOFFMAN, 1974) e a de priming. Os dois conceitos visam analisar os efeitos dos veículos de comunicação de massa nos indivíduos. Quanto ao primeiro, a perspectiva enfoca os produtores da notícia, ou seja, quem faz a seleção para que um tema seja tratado sob uma dada perspectiva (um determinado enquadramento). Já o conceito de priming ressalta os efeitos da grande mídia nos indivíduos. Claro, as duas questões não estão separadas, já que, os próprios conceitos são bastante próximos.

A função crítica do 'público' refere-se à 'publicidade'. Habermas (2003) se refere, por exemplo, ao caráter público de debates judiciais como esse. No domínio das mídias, a 'publicidade' mudou de significado, já que, de uma função da opinião pública veio a ser atributo de quem desperta a opinião pública.

Da mesma forma, demandas específicas de um governo podem influenciar a opinião pública e moldar determinadas políticas. Entendemos que a relação opinião-políticas é de natureza dialética: "Ou seja, não só a opinião pode influenciar as políticas, mas também o contrário, e uma compreensão de ambas as relações é necessária a fim de entender propriamente os fenômenos" (HOWLETT, 2000, p.185). É nesse sentido que pretendemos abordar a redução da maioridade penal no Brasil. Através de análise da repercussão de dois crimes ocorridos em 2003 e em 2007, analisamos a mobilização em torno da tramitação de propostas favoráveis a redução da maioridade penal na Câmara dos Deputados. A divulgação

\footnotetext{
${ }^{1}$ Este artigo é parte da pesquisa: "Redução da maioridade penal: Uma análise dos projetos que tramitam na Câmara dos Deputados" apoiada pela FAPESP. Agradeço à Fundação pelo financiamento. Agradeço especialmente aos pareceristas anônimos da Revista Opinião Pública pelas críticas e sugestões fundamentais feitas ao artigo.

2 Sobre opinião pública e processos políticos no Brasil, ver o trabalho de Cervi (2006) "Opinião Pública e Política no Brasil: o que o brasileiro pensa sobre política e porque isso interessa à democracia". Tese de Doutorado em Ciência Política (2006), Instituto Universitário de Pesquisas do Rio de Janeiro, Rio de Janeiro. Agradeço a Emerson Cervi e Luiz Domingos Costa pelos comentários e sugestões feitas ao artigo. A Luis Antônio Francisco de Souza agradeço especialmente pela sugestão do tema da imprensa e a orientação deste estudo.
} 
desses crimes fez vir à tona, novamente, a discussão sobre a diminuição da idade de responsabilidade penal e o suposto caráter excessivamente liberal do Estatuto da Criança e do Adolescente, fazendo com que diferentes setores da sociedade civil se posicionassem sobre a medida.

Esses debates influenciaram a Câmara dos Deputados e a apresentação de propostas favoráveis à redução da inimputabilidade penal nos períodos citados. Veículos de comunicação mobilizaram declarações do presidente da República, de atores políticos e grupos da sociedade civil e além disso, foram realizadas pesquisas de opinião sobre o tema, bem como foram veiculadas na grande mídia manifestações de atores políticos favoráveis e contrários à medida.

A hipótese deste artigo é que dois crimes de grande repercussão pública (o assassinato do casal Liana Friedenbach e Felipe Caffé, em 2003, e o assassinato do menino João Hélio, em 2007) - mobilizaram a apresentação e tramitação das Propostas de Emenda à Constituição (PEC's) favoráveis à redução da maioridade penal na Câmara dos Deputados. Para isso, analisaremos as matérias veiculadas pela revista Veja e o jornal Folha de S. Paulo nos períodos dos crimes. O material empírico pretende demonstrar como dois veículos de comunicação de massa formaram uma 'condição de fundo importante' na apresentação das propostas favoráveis à redução da maioridade penal.

O artigo está dividido da seguinte forma: primeiro, aborda questões e problemas teóricos que envolvem o conceito de opinião pública. Na segunda parte, problematiza as questões diretamente relacionadas à redução da maioridade penal e as propostas que sua aprovação. Finalmente, apresenta algumas considerações sobre o tema.

\section{Mídia e Política: construções da opinião pública}

Muitos estudos analisam a relação entre a formação de políticas e opinião pública como umarelação direta e linear. Esta ideia está relacionada com noções que compreendem a democracia como soberania popular pura e simples. As análises supõem que a opinião pública tem uma característica de concretude, quase fixa, que pode ser agregada facilmente em posições políticas coerentes (HOWLETT, 2000).

Essa concepção direta negligencia que uma das características da chamada opinião pública é o caráter abstrato, vago e transitório, e agregar as vontades coletivas em uma determinada política pública específica não é algo simples, mas de extrema complexidade. Perde-se nessas concepções a autonomia que um governo possui em relação a diferentes temas e questões, como também, se perde a complexidade dos processos de tomada de decisão governamentais nas problemáticas ligações existentes entre execução política e a publicação de 
decisões políticas e governamentais. Por último, Howlett aponta a complexidade dos processos de implementação e execução das políticas pelos funcionários do governo ${ }^{3}$.

Trabalhamos com a hipótese de que essa influência no Legislativo, através dos dois meios de comunicação aqui analisados, é possível de se verificar em alguma medida 4 . No entanto, não concebemos opinião pública como influência direta nem como entidade totalizante e racional. Entendemos o termo 'opinião pública' relacionado à influência dos meios de comunicação analisados na formação de julgamentos e atitudes dos indivíduos perante a questão da maioridade penal.

Estes indivíduos, em nossa análise, são os deputados que propuseram tais PEC's decorrentes, em partes, do frame (quadro) apresentado pela Folha de S. Paulo e, sobretudo, pela Veja nos dois crimes de grande repercussão pública analisados aqui. Não obstante, tal relação não ocorre de forma linear ou mecânica, mas atinge em maior ou menor grau as instituições políticas e os processos democráticos.

Para Ginsberg (1986), há uma concepção direta, de um Estado democrático e forte, entendido apenas como reflexo da opinião pública: ao conceberem o Estado como seu 'criado', os cidadãos das democracias ocidentais permitem que os governos possam expandir os poderes estatais. Nesse sentido, o que os cidadãos pensam ser um maior controle também pode vir a ser uma algema. Essa ideia é importante para este artigo, pois a redução da maioridade penal pode ser problematizada no mesmo sentido. Para Ginsberg, quanto mais se criam órgãos dentro do Estado, mais pode-se fortalecer o próprio Estado ao invés de necessariamente enfraquecê-lo ou fortalecer a sociedade civil.

O conceito de responsividade adquire importância nos estudos mais recentes sobre a opinião pública e processos políticos. Esse conceito é central para pensar a

\footnotetext{
${ }^{3}$ Outro exemplo, na tentativa de compreender a ligação entre opinião pública e políticas é o modelo de "ciclo de Downs". Esse ciclo entende a formação de políticas públicas como algo que gira em torno de demandas específicas, que captam a atenção do público momentaneamente. Por conseguinte, deriva em demandas por ações governamentais. Posteriormente, essas políticas específicas reivindicadas desaparecem quando suas complexidades fossem apreendidas pela atenção pública (DOWNS, 1972). Apesar da diferenciação e da introdução do termo 'ciclo', os problemas permanecem nesse tipo de análise, porque a problemática da linearidade continua fortemente presente nesta ideia. A noção de 'ciclo' não altera, como dissemos, a linearidade "do processamento das informações, da tomada de decisões e da administração por parte do governo" (HOWLETT, 2000, p. 172).

${ }^{4}$ Bourdieu $(1983,1997)$ e Champagne (1998) criticam a noção de opinião pública coerente e racional, pois, para eles tal opinião é manipulada pelos meios de comunicação de massa e pelo campo jornalístico, além de ser um bem de consumo e, portanto, consumido desigualmente entre as classes e grupos sociais. Sobre o campo jornalístico, diz Bourdieu: "O campo jornalístico impõe sobre os diferentes campos de produção cultural um conjunto de efeitos que estão ligados, em sua forma e eficácia, à sua estrutura própria, isto é, à distribuição dos diferentes jornais e jornalistas segundo sua autonomia com relação às forças externas, as do mercado dos leitores e as do mercado dos anunciantes. O grau de autonomia de um órgão de difusão se mede sem dúvida pela parcela de suas receitas que provém da publicidade e da ajuda do Estado (sob a forma de publicidade ou de subvenção) e também pelo grau de concentração dos anunciantes" (BOURDIEU, 1997, p.102-103).
} 
democracia, pois através dele busca-se identificar as ações do Estado para dar conta das demandas dos cidadãos, e porque ele relaciona o quanto os cidadãos capacitam as próprias instituições do regime democrático.

Esse é um dos dilemas de um Estado responsivo. De um lado, ele expande o poder estatal, de outro, aumenta a participação dos cidadãos. Ao definir a responsividade como fim central na relação entre governo-opinião de massa, correse o risco de propagar unilateralmente a participação dos cidadãos, o que negligencia o fortalecimento do poder estatal contra a própria sociedade civil. Nesse sentido, o voto aparece para o autor como o marco desse processo de influência da opinião pública nos processos governamentais ${ }^{5}$.

A partir do século XX, movimentos e grupos sociais, além de conquistarem o sufrágio, influenciaram a definição de algumas políticas públicas no Estado contemporâneo, forçando governos em determinadas circunstâncias a serem 'obedientes' às suas demandas. Ou seja, a emergência das instituições democráticas transformou a política ocidental e alterou substancialmente a relação do Estado, entre governantes e governados (o que o autor denomina 'a primeira grande transformação').

As ações do governo também influenciam a atenção pública, podendo utilizá-la para os interesses estatais sobre os indivíduos. Como exemplos, as propagandas sobre educação e campanhas de conscientização, entre outros mecanismos, são utilizados amplamente pelos governos para atingir determinados objetivos.

Mecanismos formais influenciam a opinião popular e um governo forte pode coexistir justamente pela existência das instituições democráticas, dando um modo formal à opinião pública, de modo que os cidadãos se posicionem e possam

\footnotetext{
${ }^{5}$ Para exemplificar o argumento, Ginsberg (1986) faz um breve histórico do voto na formação do Estado Nação. Segundo o autor, a partir do século XVIII, iniciou-se o processo de mudança na relação entre opinião pública e governo. $O$ aspecto mais importante dessa alteração foi a construção de mecanismos de consulta popular (instituições eleitorais e representação parlamentar) e a gradual extensão do direito de voto para as classes baixas no começo do século XX, nos regimes europeus. Essas modificações colocaram para os governos a obrigação de dialogar sobre seus programas e políticas. Porém, a explicação convencional crê que a extensão do direito do voto e a representação no governo são formas unicamente resultantes das demandas populares. Para o autor, ainda que o direito de voto seja constituído por lutas dos cidadãos em determinados momentos históricos, na Europa Ocidental e nos EUA, a expansão do sufrágio, e a incorporação de demandas populares em momentos históricos específicos também fortaleceram o Estado. Um exemplo desse processo, segundo o autor, foi quando o governo americano garantiu o direito de voto aos negros na década de 1960. Outro exemplo, do fortalecimento estatal, pode ser a transição democrática brasileira. Para Ginsberg, esse processo pode ocorrer por quatro circunstâncias: a expansão do voto está ligada frequentemente a esforços dos grupos que estão no poder para negociar com as massas para não desafiarem o regime; um regime que seja inviável de ser suprimido pela força pode ser confrontado por uma desordem social de tal modo; ameaças externas ou a integridade territorial (guerras por exemplo) podem expandir o sufrágio; voto popular e representação estariam associados com os esforços de centralização e expansão da autoridade nacional.
} 
beneficiar-se de um governo forte. Pode-se assim transformar a relação entre governantes e governados. A responsividade pode ser um elemento essencial para o crescimento e a possibilidade de um Estado moderno que possa oferecer mais serviços aos cidadãos. Essa é a segunda grande transformação do Estado. Para Ginsberg, os políticos incentivam a opinião pública a pressionar o Estado por demandas específicas. No entanto, é nessa segunda grande transformação que o Estado pode expandir os seus poderes: utilizando-se da atenção pública para servirse a si mesmo e fortalecendo o poder estatal, não necessariamente na direção de políticas mais democráticas.

Esse ponto, como já dissemos, é central a este artigo, pois, no princípio do século XXI, o fortalecimento estatal pode enfraquecer a significação da opinião de massa expandindo o Estado em impostos, no apoio a guerras ou, em nosso caso, no recrudescimento das punições aos adolescentes. Nesse sentido, um aumento da participação direta dos cidadãos em questões governamentais específicas pode também vir a ser uma prisão aos cidadãos nas suas relações com o Estado.

Entendemos, no mesmo sentido de Howlett (2000), que os efeitos da opinião pública sobre as políticas não são diretos, mas significativos. Essa influência não ocorre de forma linear, mas de forma dialética: a opinião pública afeta as políticas e as políticas afetam a atenção pública. A opinião pública se constitui como 'pano de fundo', um 'locus' no qual é um elemento importante em que o processo político se produz.

Tal efeito pode refletir sobre as instituições políticas através do impacto duradouro em um tema debatido na chamada opinião pública. O conceito de priming adquire importância em nossa análise. Entendido como extensão da agenda setting $^{6}$, entende-se que a formação de julgamentos e atitudes dos indivíduos, perante determinadas questões, está relacionada a determinados casos ou associações trazidas à mente pela grande mídia. Tal premissa tem por base que: (a) as pessoas processam as informações mais acessíveis; (b) a mídia de massa, nesse sentido, pode formar as considerações, julgamentos, que as pessoas fazem sobre determinados candidatos ou assuntos (SCHEUFELE \& TEWKSBURY, 2007).

Já o conceito de framing distingue-se dos dois modelos (agenda-setting e priming), de acordo com Scheufele \& Tewksbury (2007), pois concebe que o modo como um dado assunto é caracterizado em novas reportagens ou matérias pode influenciar o entendimento do público sobre a temática retratada. Na perspectiva do interacionismo simbólico Goffman (1974), assume que os indivíduos interpretam suas experiências de acordo com o mundo ao seu redor. Estão, portanto, em constante luta para interpretar suas experiências de vida e fazer sentido ao mundo que os rodeia.

6 O conceito de agenda-setting indica a importância com que a mídia de massa aborda determinados assuntos formatando a "agenda do público" e vice-versa, num efeito circular. 
No que diz respeito ao processamento de novas informações, Goffman argumenta que os indivíduos aplicam esquemas interpretativos, ou seja, usam a "estrutura primária" para classificar a informação e interpretar seus significados. Framing seria uma construção que atua mais no nível macro, ou seja, na forma de como a mídia de massa divulga uma informação; e, no nível micro, o conceito descreve como as pessoas usam essa informação e apresentam determinados assuntos, formando suas impressões para interpretar os seus significados.

Como rápido exemplo, podemos citar algumas políticas de segurança pública no Brasil que foram influenciadas pela ampla divulgação dos grandes meios de comunicação. Os trabalhos de Teixeira (2006) e Haber (2007) demonstram como a aprovação da Lei 10.792 de 2003, que instituiu o Regime Disciplinar Diferenciado (RDD), foi influenciada, dentre outros fatores, pela cobertura da mídia sobre as rebeliões do PCC (Primeiro Comando da Capital) em São Paulo, no episódio conhecido como a 'megarrebelião' em 18 de fevereiro de 2001.

Na próxima seção, através dos dados coletados, analisaremos como se dá a constituição da repercussão pública dos crimes ocorridos nos meios de comunicação de massa. A partir dessa atenção pública para o tema, a opinião pública cria uma 'condição de fundo' importante no reaparecimento do debate sobre a redução da maioridade penal. Essas questões podem nos ajudar a compreender tal relação através da emergência das discussões sobre a redução da maioridade penal no Brasil.

\section{O debate sobre as propostas favoráveis a redução da maioridade penal}

A redução da maioridade penal vem sendo debatida na sociedade brasileira há pelo menos uma década. Trata-se de uma discussão profundamente polarizada, abrangendo grupos favoráveis e contrários às mudanças, baseando seus argumentos tanto em problemas de ordem pública - os jovens vistos como criminosos perigosos - quanto em questões de proteção das faixas sociais mais vulneráveis - os jovens vistos como tuteláveis pelo estado.

O Estatuto da Criança e do Adolescente, promulgado em 1990 (lei 8.069), teve a participação de especialistas de diferentes áreas na sua elaboração. O ECA, no plano formal, colocou a questão da infância e juventude no centro do ordenamento jurídico brasileiro, em consonância com os movimentos internacionais de direitos e proteção da criança e do adolescente como sujeitos de direitos. Vale citar que o ECA já contém medidas socioeducativas (incluindo a internação) no caso da prática de ato infracional por crianças e adolescentes entre 12 e 18 anos $^{7}$.

\footnotetext{
7 "Medidas socioeducativas do ECA: I - advertência; II - obrigação de reparar o dano; III - prestação de serviços à comunidade; IV - liberdade assistida; V - inserção em regime de semiliberdade; VI internação em estabelecimento educacional (com período máximo de três anos); VII - qualquer uma das
} 
Embora muitas disposições do ECA ainda não tenham sido efetivadas, como, por exemplo, com relação aos adolescentes infratores, assistimos à emergência de um discurso que reivindica "deveres" e não apenas (como dizem muitos deputados nas proposições) "direitos" para os jovens. O Estatuto é tido para alguns setores da sociedade brasileira, do mesmo modo que para alguns deputados autores dos projetos de lei, como sinônimo de impunidade, e liberal demais para a punição do adolescente autor de ato infracional.

Em meio a esse contexto, emergem o discurso e as propostas favoráveis à redução da maioridade penal, sobretudo em períodos subsequentes a crimes de grande repercussão pública. Os meios de comunicação dão grande destaque a atos de violência cometidos por (ou supostamente atribuídos) a crianças e jovens, geralmente pobres, destaque seguido frequentemente pela crítica ao ECA e pela defesa da redução da idade penal como principal alternativa frente ao suposto crescimento da criminalidade infantil e juvenil (ALVAREZ, 1997).

O "clamor social" em relação ao jovem infrator, como dissemos, emerge da ideia de que nada acontece a ele quando autor de ato infracional. Para os deputados que criticam o Estatuto, a instauração efetiva do ECA ${ }^{8}$ não "enfrenta" a questão dos crimes praticados por jovens.

previstas no art. 101, I a VI (I - encaminhamento aos pais ou responsável, mediante termo de responsabilidade; II - orientação, apoio e acompanhamento temporários; III - matrícula e frequência obrigatórias em estabelecimento oficial de ensino fundamental; IV - inclusão em programa comunitário ou oficial de auxílio à família, à criança e ao adolescente; $V$. requisição de tratamento médico, psicológico ou psiquiátrico, em regime hospitalar ou ambulatorial; VI - inclusão em programa oficial ou comunitário de auxílio, orientação e tratamento a alcoólatras e toxicômanos."

8 Estudo do Governo federal intitulado "Adolescentes em conflito com a lei - reflexões para uma prática qualificada" de 1997, coloca que as medidas sócio-educativas não estão sendo cumpridas conforme a norma legal, visto que, a medida de internação vem sendo aplicadas na maioria dos casos em relação às medidas alternativas que privilegiam o atendimento em sistema aberto como a prestação de serviços à comunidade, a obrigação de reparar o dano, a liberdade assistida. Os dados oficiais revelam que a medida de internação (privativa de liberdade) aplicada aos que cometem ações graves é a única das quatros medidas executadas em todas unidades da federação (100\%), enquanto as outras são: internação provisória (78\%), semiliberdade e a liberdade assistida (74\%), e prestação de serviços à comunidade $(52 \%)$ nas unidades da federação. Quanto à competência de quem aplica as medidas - 0 Poder Judiciário - $(76,9 \%)$ dos encaminhamentos são feitos pela atividade judiciária, ministério público (16\%), Polícia Civil (3,3\%), e Conselho Tutelar (0,5\%). Já no total de instituições que executam o projeto pedagógico de atendimento: $39 \%$ afirmam possuir projeto em execução; $28,5 \%$ disseram não possuir qualquer projeto e $31,5 \%$ não responderam. (PEREIRA, 2001) 


\section{As Propostas de Emenda à Constituição (PEC’S)}

As justificativas das diferentes propostas de emenda à Constituição que tramitam no Congresso Nacional $^{9}$ baseiam-se desde o direito de voto dos adolescentes a partir dos 16 anos até a alegação de que o limite válido atualmente é condizente com uma época em que a maturidade dos adolescentes era alcançada em idades mais avançadas. Para os deputados, os jovens não possuíam em outras épocas as condições de formação atuais, podendo ser responsáveis penalmente aos 16 ou até 14 anos de idade. O Quadro 1, a seguir, faz um mapeamento do debate na Câmara dos Deputados desde 1993 a 2007:

\section{Quadro 1 \\ Propostas de Emendas à constituição sobre a redução da maioridade penal (1993 a 2007)}

\begin{tabular}{|c|c|c|c|c|c|}
\hline ID & PROJETO & DATA & AUTOR/DEP & PARTIDO & INIMPUTABILIDADE \\
\hline 1 & PEC No 171 & 26/10/1993 & $\begin{array}{l}\text { Benedito } \\
\text { Domingos }\end{array}$ & $P P-D F$ & 16 anos \\
\hline 2 & PEC N 37 & 23/03/1995 & Telmo Kirst & PPR - RS & 16 anos \\
\hline 3 & PEC Nº 91 & $10 / 05 / 1995$ & $\begin{array}{l}\text { Aracely de } \\
\text { Paula }\end{array}$ & $P L-M G$ & 16 anos \\
\hline 4 & PEC N 301 & $11 / 01 / 1996$ & Jair Bolsonaro & $P P-R J$ & 16 anos \\
\hline 5 & PEC N 386 & $11 / 06 / 1996$ & Pedrinho Abrão & PTB - GO & 16 anos para alguns crimes \\
\hline 6 & PEC N ${ }^{\circ} 426$ & $06 / 11 / 1996$ & $\begin{array}{l}\text { Nair Xavier } \\
\text { Lobo }\end{array}$ & PMDB - GO & 16 anos \\
\hline 7 & PEC N ${ }^{\circ} 531$ & $30 / 09 / 1997$ & Feu Rosa & $P P-E S$ & 16 anos \\
\hline 8 & PEC N ${ }^{\circ} 633$ & 06/01/1999 & Osório Adriano & $P F L-D F$ & $\begin{array}{c}\text { 16-18 anos com ou sem } \\
\text { emancipação }\end{array}$ \\
\hline 9 & PEC N 68 & $30 / 06 / 1999$ & $\begin{array}{l}\text { Luís Antônio } \\
\text { Fleury/ } \\
\text { Íris Simões }\end{array}$ & $\begin{array}{l}\text { PTB - SP } \\
\text { PTB - PR }\end{array}$ & 16 anos \\
\hline
\end{tabular}

\footnotetext{
9 Atualmente tramitam 29 PEC'S propondo a redução da maioridade penal para 16 anos, 14 anos ou até 12 anos na Comissão de Constituição CCJC (Comissão de Constituição e Justiça e de Cidadania) da Câmara dos Deputados desde 1993 até 2007. Proposta de Emenda à Constituição (PEC) é uma atualização, um emendo à Constituição Federal. É uma das propostas que exige mais tempo para preparo, elaboração e votação, uma vez que modificará a Constituição Federal. Em função disso, requer quórum quase máximo e dois turnos de votação em cada uma das Casas legislativas, Câmara dos Deputados e Senado Federal.
} 
CAMPOS, M.S. Mídia e Política: a construção da agenda nas propostas...

\begin{tabular}{|c|c|c|c|c|c|}
\hline 10 & PEC N ${ }^{\circ} 133$ & $13 / 10 / 1999$ & Ricardo Izar & PTB - SP & 16 anos \\
\hline 11 & PEC N ${ }^{\circ} 150$ & $10 / 11 / 1999$ & Marçal Filho & PMDB - MS & 16 anos \\
\hline 12 & PEC N ${ }^{\circ} 167$ & $24 / 11 / 1999$ & $\begin{array}{c}\text { Ronaldo } \\
\text { Vasconcellos }\end{array}$ & PTB - MG & 16 anos \\
\hline 13 & PEC No 169 & 25/11/1999 & Nelo Rodolfo & PMDB - SP & 14 anos \\
\hline 14 & PEC N ${ }^{\circ} 260$ & $13 / 06 / 2000$ & $\begin{array}{c}\text { Pompeo de } \\
\text { Mattos }\end{array}$ & PDT - RS & 17 anos \\
\hline 15 & PEC N ${ }^{\circ} 321$ & $13 / 02 / 2001$ & Alberto Fraga & $P F L-D F$ & aspectos psicossociais do agente \\
\hline 16 & PEC N ${ }^{\circ} 377$ & $20 / 06 / 2001$ & $\begin{array}{l}\text { Jorge Tadeu } \\
\text { Mudalen }\end{array}$ & PMDB - SP & 16 anos \\
\hline 17 & PEC N 582 & $28 / 11 / 2002$ & Odelmo Leão & $P P-M G$ & 16 anos \\
\hline 18 & PEC N ${ }^{\circ} 64$ & $22 / 05 / 2003$ & André Luiz & PMDB - RJ & 16-18 anos casos excepcionais \\
\hline 19 & PEC N ${ }^{\circ} 179$ & $08 / 10 / 2003$ & Wladimir Costa & PMDB - PA & 16 anos \\
\hline 20 & PEC N ${ }^{\circ} 242$ & $04 / 03 / 2004$ & $\begin{array}{c}\text { Nelson } \\
\text { Marquezelli }\end{array}$ & PTB - SP & 14 anos \\
\hline 21 & PEC N ${ }^{\circ} 272$ & $11 / 05 / 2004$ & Pedro Corrêa & $P P-P E$ & 16 anos \\
\hline 22 & PEC N 302 & $07 / 07 / 2004$ & Almir Moura & PL-RJ & $\begin{array}{l}16 \text { anos com parecer em } \\
\text { contrário de junta médico- } \\
\text { jurídica, na forma de Lei, } \\
\text { ratificado pelo juízo competente }\end{array}$ \\
\hline 23 & PEC N 345 & $06 / 12 / 2004$ & Silas Brasileiro & PMDB.MG & 12 anos \\
\hline 24 & PEC N 489 & $07 / 12 / 2005$ & Medeiros & PL.SP & $\begin{array}{c}\text { prévia avaliação psicológica, } \\
\text { podendo o juiz concluir pela sua } \\
\text { imputabilidade, se julgar que o } \\
\text { seu grau de maturidade justifica a } \\
\text { aplicação da pena }\end{array}$ \\
\hline 25 & PEC N ${ }^{\circ} 48$ & $19 / 04 / 2007$ & Rogério Lisboa & DEM - RJ & 16 anos \\
\hline 26 & PEC N ${ }^{\circ} 73$ & $30 / 05 / 2007$ & Alfredo Kaefer & PSDB - PR & $\begin{array}{c}\text { capacidade de entender o caráter } \\
\text { delituoso do fato e de } \\
\text { autodeterminar-se conforme esse } \\
\text { entendimento através de audo } \\
\text { médico e psicológico }\end{array}$ \\
\hline
\end{tabular}




\begin{tabular}{|c|c|c|c|c|c|}
\hline 27 & PEC N ${ }^{\circ} 85$ & $06 / 06 / 2007$ & Onyx Lorenzoni & DEM-RS & $\begin{array}{c}16 \text { anos - nos crimes dolosos } \\
\text { contra a vida, jovem será } \\
\text { avaliado por } \\
\text { uma equipe multiprofissional } \\
\text { constituída pela autoridade } \\
\text { judiciária e emancipado para } \\
\text { efeitos penais, se ficar } \\
\text { constatado, mediante laudo } \\
\text { emitido pela equipe designada } \\
\text { pelo juiz, que, ao } \\
\text { tempo da ação, ele tinha } \\
\text { consciência do caráter ilícito do } \\
\text { fato e condições de determinar-se } \\
\text { de acordo com esse } \\
\text { entendimento. }\end{array}$ \\
\hline 28 & PEC N ${ }^{\circ} 87$ & $12 / 06 / 2007$ & $\begin{array}{l}\text { Rodrigo de } \\
\text { Castro }\end{array}$ & PSDB - MG & $\begin{array}{c}\S 1^{\circ} \text { Considerar-se-á imputável o } \\
\text { menor de dezoito anos que } \\
\text { praticar crime doloso contra a } \\
\text { vida, ou inafiançável e } \\
\text { insuscetível de graça ou anistia, } \\
\text { ou imprescritível. } \\
\S 2^{\circ} \text { Comprovada a incapacidade } \\
\text { do menor de dezoito anos de } \\
\text { entender o caráter ilícito do fato } \\
\text { ou de determinar-se de acordo } \\
\text { com esse entendimento, poderá } \\
\text { o juiz considerá-lo } \\
\text { inimputável. }\end{array}$ \\
\hline 29 & PEC N ${ }^{\circ} 125$ & $12 / 07 / 2007$ & $\begin{array}{l}\text { Fernando de } \\
\text { Fabinho }\end{array}$ & $\mathrm{DEM} \cdot \mathrm{BA}$ & $\begin{array}{c}\text { estabelece que a imputabilidade } \\
\text { será determinada por decisão } \\
\text { judicial, baseada em fatores } \\
\text { psicossociais e culturais do } \\
\text { agente, e nas circunstâncias em } \\
\text { que foi praticada a infração } \\
\text { penal. }\end{array}$ \\
\hline
\end{tabular}

\section{Repercussão pública dos crimes praticados por menores em 2003 e 2007}

Nessa seção, abordamos a cobertura realizada por dois meios de comunicação de grande circulação: Folha de S. Paulo e Revista Veja sobre os crimes ocorridos em 2003 em São Paulo, e 2007 no Rio de Janeiro. Em seguida apresentamos fragmentos de algumas PEC'S apresentadas no período subsequente aos crimes, e dialogamos com Howlett (2000) e outros autores para uma análise das (des) continuidades entre meios de comunicação e prática política.

Cabe, ainda que brevemente, justificar o interesse na análise da imprensa escrita. Primeiro, analisar o material televisivo (que detém certamente maior alcance entre diferentes grupos e classes sociais) implicaria em uma análise de 
discursos, entre outras questões da mídia televisiva que não pretendemos adentrar neste artigo. Segundo a imprensa escrita ainda detém o poder de influenciar o debate público sobre uma dada questão. Weber (2002) assinala que a imprensa introduz e reintroduz deslocamentos poderosos nos hábitos de leitura dos indivíduos. Com isso, produz alterações no modo como o homem capta e interpreta o mundo exterior, pois: "A constante mudança e o fato de se dar conta das mudanças massivas da opinião pública, de todas as possibilidades universais e inesgotáveis dos pontos de vista e dos interesses, pesa de forma impressionante sobre o caráter específico do homem moderno" (WEBER, 2002, p.193). Em seguida apresentamos as matérias veiculadas.

\section{Folha de S. Paulo - 2003}

No dia 10/11/2003, o assassinato do casal Liana Friedenbach, 16, e Felipe Silva Caffé, de 19 anos, em Embu-Guaçu, na Grande São Paulo envolveu quatro adultos e um adolescente de apelido "Champinha", na época, com 16 anos. O crime foi amplamente veiculado pelos meios de comunicação. Na Folha de São Paulo foram encontradas 125 ocorrências entre os dias 10/11/2003 (dia do assassinato de Liana e Felipe) e 11/06/2004 (um mês após a PEC do Dep. Pedro Corrêa). Citaremos aqui alguns exemplos de matérias sobre o crime. Visto o grande número de registros sobre o assunto no período abordado, mencionaremos apenas alguns exemplos.

Em 12/11/2003, no caderno Folha Brasil, a matéria intitulada "Deputados se insultam ao discutir questão" relatava que os deputados Jair Bolsonaro (PTB-RJ) e Maria do Rosário (PT-RS) se agrediram aos gritos em uma discussão na Câmara sobre a questão da redução da maioridade penal para 16 anos. Após conceder uma entrevista à emissora de TV, Bolsonaro teria dito à deputada: "Se a senhora é contra a redução da maioridade, pega aquele estuprador de São Paulo [que matou um casal de estudantes] e leva para a sua casa". Maria do Rosário teria dito que o problema da criminalidade era decorrência de pessoas como ele. Segundo Bolsonaro, ela o teria chamado de "estuprador" e teria ameaçado Ihe dar um tapa. Ele teria a chamado de "vagabunda".

Em 15/11/2003, no caderno Cotidiano, na matéria "Crime reabre debate sobre maioridade penal", a coordenadora da Pastoral da Criança, Zilda Arns, defendeu a realização de um plebiscito sobre esse tema. Já a representante da CNBB, Márcia Accioli, disse que a entidade é "oficialmente contra a redução da maioridade penal". O arcebispo dom Cláudio Hummes também afirmou ser contra a medida. Na mesma matéria, o presidente do TST (Tribunal Superior do Trabalho), ministro Francisco Fausto, defendeu a redução da maioridade penal para 16 anos. O então ministro do STF (Supremo Tribunal Federal), Nelson Jobim, considerou que 
a redução da maioridade penal teria como consequência a superlotação das cadeias e o ex-secretário especial de Direitos Humanos, Nilmário Miranda reforçou sua posição contrária à redução. José Fernando da Silva, vice-presidente do Conanda (Conselho Nacional dos Direitos da Criança e do Adolescente), alegou que "é preciso acreditar na ressocialização" e o presidente da seccional paulista da OAB (Ordem dos Advogados do Brasil), Carlos Miguel Aidar, disse que as experiências de redução da maioridade realizadas no mundo inteiro se mostraram frustrantes, não havendo redução da criminalidade.

Esses exemplos mostram que o crime ocorrido em Embu-Guaçu, trouxe a discussão sobre a maioridade penal para a grande imprensa. O jornal Folha de São Paulo, aqui analisado, cobriu exaustivamente a questão, publicando, sobretudo opiniões contrárias à redução da idade penal, o que também defendeu em seus editoriais. Mas também procurou colocar pontos de vistas favoráveis à medida, como mostramos alguns exemplos

Pela cobertura da Folha, vimos também que não houve declaração publicada de membros do PT, PCdoB, PSB ou algum outro partido caracterizado no quadro partidário brasileiro tradicionalmente como de esquerda favorável à medida, embora o presidente Lula tenha se manifestado favorável a uma revisão do ECA nos moldes do projeto do governador Geraldo Alckmin.

A mesma constatação ocorre quanto à autoria das PEC's. Vimos, na Quadro 1 , que quase nenhum dos partidos localizados no espectro político-partidário de esquerda ou centro-esquerda propôs a redução da inimputabilidade penal, exceto um projeto proposto pelo PDT (ex-deputado Pompeo de Mattos). Vale ressaltar, por outro lado, que a maioria das propostas são de autoria dos deputados vinculados aos partidos localizados no centro do espectro partidário: PSDB e PMDB, e centrodireita: PP, PPR, DEM (Ex-PFL), PL, PTB ${ }^{10}$.

Claro, há divergências individuais quanto à questão da redução da inimputabilidade penal dentro desses partidos, como Rita Camata, do PMDB, que declarou-se contrária à medida. Há, da mesma forma, deputados e senadores de partidos de esquerda que apóiam a questão. No entanto, quanto à autoria dos projetos e as declarações na imprensa no período que pesquisamos, em nenhum momento, encontramos PT ou PCdoB, por exemplo, apoiando publicamente à medida.

Sabemos que essas divisão e conceitualização são, de certo modo, arbitrárias, uma vez que a distância entre esses dois campos políticos diminuiu de forma significativa nos últimos anos, e, constantemente, observamos a inversão de papéis entre governantes de esquerda e de direita. No entanto, como bem observou Almeida (2006), "enquanto a igualdade entre as pessoas for um valor moral e

10 Tal classificação do espectro-político dos partidos foi baseada na análise de Rodrigues (2002). 
político amplamente compartilhado e enquanto sociedades e mercados continuarem produzindo desigualdades de vários tipos, os termos esquerda e direita continuarão a fazer sentido".

Com relação à revista Veja nesse caso, a cobertura está a seguir:

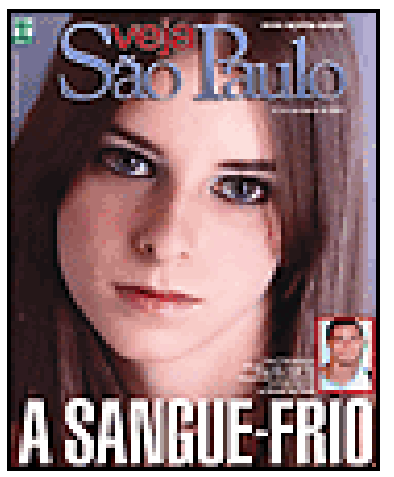

A imagem acima reproduz a capa da Veja São Paulo em 19 de novembro de 2003. Nessa revista, a reportagem da capa defendeu a redução da maioridade penal, alegando que o jovem que cometeu o crime iria ficar "no máximo três anos na Febem", enquanto os outros envolvidos poderiam ficar até 30 anos na prisão. A matéria critica a atual inimputabilidade penal utilizando-se de argumentos muito parecidos com os deputados. Nessas abordagens, aparece a idéia de que o jovem é uma pessoa em formação e o Código Penal de 1940, que estabeleceu a idade penal aos 18 anos, era válido em outras épocas mas não na sociedade contemporânea. Tanto é que a Constituição reconheceu isso, segundo a reportagem, quando concedeu direito de voto aos 16 anos: "Ou seja, rapazes e moças que nem entraram na faculdade estão aptos para escolher o presidente da República, mas não estão sujeitos a uma condenação penal, cometam o delito que cometerem.", diz a reportagem da Veja São Paulo11.

Os argumentos veiculados pela revista Veja, como veremos quando tratarmos de justificativas dos deputados para as PEC's, são semelhantes aos discursos dos deputados favoráveis à redução da maioridade penal.

11 Ainda segundo a matéria, a discussão não deve-se dar em razão do clamor público com esse crime, pois o debate exige serenidade: "Uma redução indiscriminada para 16, 15, 14 anos, ou a idade que for, atingiria tanto bárbaros homicidas quanto adolescentes apanhados consumindo drogas. Nos dois casos, eles iriam para a cadeia ao lado de criminosos comuns". 


\section{PEC's de 2004}

As PEC's apresentadas no período posterior ao crime de 2003 foram às Propostas de Emenda à Constituição (PEC) $N^{\circ} 242$, de 2004, do deputado Nelson Marquezelli PTB-SP e a PEC N²72, também de 2004, do deputado Pedro Corrêa PP.PE.

A Proposta de Emenda à Constituição de Nelson Marquezelli (PTB-SP) foi apresentada em Plenário no dia 04 de março de 2004; no dia 18 de março de 2004 a proposta foi recebida. A proposição não tem uma justificação extensa, nem possui um argumento central para a defesa da fixação da responsabilidade penal aos quatorze anos.

O deputado inicia a defesa de seu projeto comentando que, tanto pelo homicídio do casal de jovens Liana Friedenbach e Felipe Silva Caffé como, pela constante escalada da violência no Brasil, faz-se necessário "modificarmos a política legislativa concernente à inimputabilidade penal". O deputado também menciona que os jovens já possuem maturidade para responder por seus atos ilícitos, pois, segundo Marquezelli, vivemos na "era da informação", na qual os jovens estão atualmente expostos aos mais diversos tipos de conhecimento do que há tempos atrás.

O deputado Pedro Corrêa PP.PE apresentou seu projeto em 11 de maio do mesmo ano. No início da justificação, o deputado afirmou que a atual imputabilidade penal é algo "melindroso" e merece revisão. Pedro Corrêa diz que a população está amedrontada em suas casas vendo todos os dias "crimes violentos praticados por menores de dezoito anos, ou com sua participação". A proposta é algo premente, diz ele, porque irá beneficiar os próprios jovens que poderão dirigir legalmente com a alteração da legislação. Nas palavras do deputado: "Obviamente não daqueles jovens que se escudam na idade para praticar delitos, mas daqueles de boa índole, de caráter probo e honesto". Segundo Corrêa, é uma tendência "de quase todos os países civilizados" reduzir a maioridade penal ${ }^{12}$.

\footnotetext{
12 Sobre esse aspecto, segundo Leal (2003), estudos comparativos demonstram que aproximadamente $60 \%$ dos países utilizam a responsabilidade penal aos 18 anos e as Regras de Beijing, adotadas pela Assembleia Geral da ONU pela resolução n. 40/33, de 29 de novembro de 1985, assinalava que a idade penal deveria ser sempre ampliada. Além do mais, devido às condições das penitenciárias brasileiras, diminuir a idade penal seria atestar a nossa incapacidade de lidar com o problema da criminalidade infanto-juvenil. Eugênio Couto Terra (2001) lista alguns países que estabelecem a maioridade penal (imputabilidade penal) com menos de 18 anos: Bolívia (16); Egito (15); Polônia (17); Paraguai (15 anos); EUA entre 6 e 18 anos, conforme a legislação estadual; Inglaterra 10 anos. Portugal adota a maioridade penal aos 16 anos, havendo um regime penal diferenciado doa 16 até 21 anos. França, por exemplo, adota tribunais especiais dos 13 anos aos 18 anos. Este é o caso da Espanha também que adota a idade de responsabilidade penal juvenil dos 12 aos 18 anos; Alemanha 14 anos; Itália 14 anos; Peru 12 anos. No entanto, em muitos desses países, a maioridade penal (imputabilidade penal) é fixada aos 18 anos.
} 


\section{Folha de São Paulo 2007 - Crime João Hélio}

A busca nos arquivos do Jornal Folha de S. Paulo da expressão 'maioridade penal' encontrou 168 ocorrências no período, entre 07/02/2007 (dia do assassinato do garoto João Hélio) até o dia 12/08/2007. A expressão maioridade penal encontrou maior número de ocorrências no jornal do que as notícias do crime ocorrido (a busca com a expressão 'crime João Hélio', no mesmo período, encontrou 102 ocorrências). Vejamos alguns exemplos.

No dia 10/02/2007, o governador do Rio de Janeiro declarou que era necessário discutir a redução da maioridade penal e defendeu a autonomia dos estados para legislar sobre questões penais (declaração relatada na matéria "Para Sérgio Cabral, legislação precisa mudar", publicada no caderno cotidiano da Folha de São Paulo). A presidente do Supremo Tribunal Federal, a ministra Ellen Gracie Northfleet, disse ser contra a redução da maioridade penal; o ministro do STF, Carlos Ayres Britto, emitiu opinião semelhante, mas defendeu mudanças no Estatuto da Criança e do Adolescente (ECA). No mesmo dia, a matéria do caderno Cotidiano 'Lula descarta redução da maioridade penal', o presidente Luiz Inácio Lula da Silva manifestou-se contrariamente à medida e também se opôs ao aumento de eventuais medidas punitivas.

No dia 18/02/2007, o filósofo Renato Janine Ribeiro escreveu no caderno Mais o artigo 'Razão e sensibilidade', no qual declarou ser favorável à pena de morte à luz da morte de João Hélio:

\footnotetext{
"Se não defendo a pena de morte contra os assassinos, é apenas porque acho que é pouco. Não paro de pensar que deveriam ter uma morte hedionda, como a que infligiram ao pobre menino. Imagino suplícios medievais, aqueles cuja arte consistia em prolongar ao máximo o sofrimento, em retardar a morte..."13
}

No dia 27/04/2007, no Caderno Cotidiano, a matéria 'Comissão reduz maioridade penal para 16' relatou que a "Comissão de Constituição e Justiça" do Senado aprovou por 12 votos a 10 a redução da maioridade penal de 18 para 16 anos no caso de tráfico de drogas, tortura, terrorismo e crime hediondo (como homicídio qualificado, sequestro, estupro e roubo seguido de morte). 0 menor de idade só será preso, porém, se uma junta nomeada pelo juiz atestar, por laudo técnico, que ele tinha discernimento dos seus atos. Foi incluída a ressalva de que, se condenado, ele cumprirá pena em local separado dos presos maiores de 18 anos. No mesmo dia, a matéria 'Efeito João hélio: senado votou 20 projetos de

13 Segundo Ribeiro: “A punição com a morte se justifica ora pela gravidade do crime cometido, ora pela descrença de que o criminoso se possa recuperar. No caso, as duas razões comparecem. Parecem irrecuperáveis, e seu crime é hediondo. Não vejo diferença entre eles e os nazistas." 
segurança' relata que o Senado votava, desde fevereiro de 2007, vinte projetos na área de segurança endureciam a legislação penal e reformavam o sistema penitenciário.

Vale citar, antes de passarmos à cobertura da Revista Veja, que a matéria relatou partidos contrários e favoráveis a proposta de redução e algumas declarações dos senadores:

"Na base do governo, PT, PTB e PSB ficaram unidos na rejeição da proposta, mas o PMDB votou majoritariamente a favor, com exceção do líder do governo, Romero Jucá (RR), e de Pedro Simon (RS). Jefferson Peres (PDT-AM), que agora faz parte da coalizão, também votou contra o governo. 'Repilo veementemente essa história de culpa coletiva, de que o menor virou um monstrinho por culpa da desigualdade social. Quero que menores que cometeram crimes graves e forem avaliados como irrecuperáveis sejam segregados da sociedade', disse Jefferson Peres. Já a oposição votou em bloco a favor da emenda, menos Lúcia Vânia (PSDB-GO)."

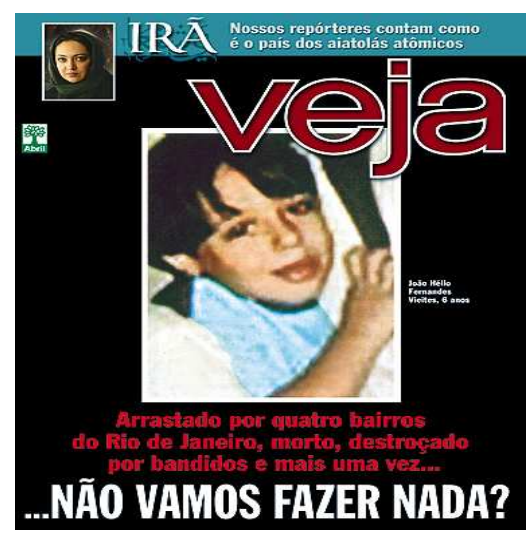

Capa Revista Veja, 14/02/2007

Na edição do dia 14/02/2007, a revista Veja trouxe a matéria 'Sem limites para a barbárie'. No decorrer da matéria, foram indicados algumas soluções inéditas para a violência urbana:

"Suspender o limite para a internação de adolescentes infratores em centros de ressocialização. Hoje, eles só podem ficar internados até os 18 anos. 'Só deveriam poder deixar os centros aqueles adolescentes que estivessem realmente ressocializados. E isso poderia durar três, quatro ou dez anos', afirma Testa."

$\mathrm{Na}$ edição da semana seguinte, 21/02/07, a matéria 'Crime - Mais uma marola em Brasília' relatava que o debate sobre a Maioridade havia sido retomado no 
Senado, apesar da lentidão do Parlamento na questão da segurança pública. O debate só foi retomado, segundo a matéria, em razão do crime no Rio de Janeiro: "O assassinato brutal do menino João Hélio Fernandes Vieites, de 6 anos, fez com que os parlamentares brasileiros decretassem guerra contra a bandidagem.". Em 08/08/2007, Reinaldo Azevedo ainda abordaria o tema no artigo 'O Movimento dos Sem-Bolsa', relatando as vaias ao presidente Lula e exaltando o movimento 'Cansei' em São Paulo. Segundo Azevedo:

"Um grito de protesto da classe média é ilegítimo? É ela hoje o verdadeiro 'negro' do Brasil. Ninguém a protege: estado, ONG, igrejas, nada... Corajosa, sem líder, sozinha, sem tucano, vaiou no Rio, vaiou em São Paulo, quer vaiar no Brasil inteiro... O país cobra a maioridade penal aos 16 anos? Eles esperam passar o clamor".

\section{PEC's de 2007}

No período posterior ao assassinato de João Hélio, foram apresentadas as PEC's $N^{\circ} 48$, no dia 19/04/2007, do deputado Rogério Lisboa (DEM-RJ); $N^{\circ} 73$, no dia 30/05/2007, do deputado Alfredo Kaefer (PSDB-PR); $N^{\circ}$ 85, no dia 06/06/2007, do deputado Onyx Lorenzoni (DEM-RS) e No 87, no dia 12/06/2007, do deputado Rodrigo de Castro (PSDB-MG).

Na proposta $N^{\circ} 48$, favorável à redução da maioridade para dezesseis anos, o deputado Rogério Lisboa, citava como motivos para reduzir a maioridade "a alarmante escalada da criminalidade, que em uma de suas vertentes contemporâneas mais evidentes revela a utilização cada vez mais intensa de menores de dezoito anos de idade, seja na prática de pequenos delitos, seja no seio do crime organizado." Para o deputado, se o menor de dezesseis anos tem maturidade e discernimento para o exercício de direito político não pode ser tratado como inimputável.

O deputado Alfredo Kaefer, que propôs a PEC No 73 , defendeu que o critério fosse independente da idade, pois, "com relação ao fato importantíssimo da vida humana e sua garantia, não há como ignorar o fato, a verdade, de que bem mais cedo é apercebida por eles a obrigatoriedade de respeitá-la e preservá-la. A idade por si só não é fator determinante do desconhecimento do ético e não ético, moral ou imoral, justo ou injusto".

Já Onyx Lorenzoni (DEM-RS) citou, explicitamente, o crime de João Hélio como motivo para reduzir a idade penal para dezesseis anos nos crimes contra a vida:

Além de adequar a legislação ao momento atual, a iniciativa será mais uma contribuição do Parlamento para o combate ao crime organizado, cujas quadrilhas recrutam, com habitualidade crescente, jovens entre 16 e 18 
anos para suas ações criminosas. O caso do garoto João Hélio, arrastado brutalmente pelos subúrbios do Rio de Janeiro, é apenas mais um exemplo do envolvimento de menores em atividades delituosas".

O deputado Rodrigo de Castro (PSDB-MG), por sua vez, tratou em seu projeto a idade penal como não fixada, mas estabeleceu como critérios os "crimes contra a vida ou inafiançável e insuscetível de graça ou anistia, ou imprescritível (prática de tortura, tráfico ilícito de entorpecentes e drogas afins, terrorismo e os definidos como hediondos - art. $5^{\circ}$, inciso XLIII) e os inafiançáveis e imprescritíveis (prática de racismo, ação de grupos armados contra a ordem constitucional - art. $5^{\circ}$, incisos XLII e XLV)". Diz o deputado do PSDB: "O incremento quantitativo e qualitativo da criminalidade e o envolvimento de menores nos delitos têm levado a população a questionar a menoridade penal..."

Por último, o deputado Fernando de Fabinho (DEM-BA), que apresentou uma PEC em 12/07/2007, definiu que a imputabilidade deveria ser determinada por decisão judicial proferida em cada caso, com base no fundamento dos fatores psicossociais e culturais do agente nas circunstâncias em que foi praticada a infração penal. Sua proposta foi motivada pela superação do aspecto biológico, pleiteado na Constituição segundo o deputado, para que se avaliassem os aspectos psicossociais e culturais do agente.

\section{Redução da maioridade penal e opinião pública: possíveis processos e efeitos}

Após apresentar as propostas e a cobertura de dois meios de comunicação de massa, tentaremos relacionar esse material empírico com as reivindicações favoráveis à redução da maioridade penal no país. Para tal empreitada, é necessário reconhecer, como cita Miguel (2002), a centralidade da mídia ${ }^{14}$ na vida política contemporânea sem alimentar a ideia de que a política teve tempos áureos ou de 'verdadeiros' debates de ideias (sem preocupar-se com a imagem ou formas de publicidade), nessa perspectiva, parte dos problemas que a mídia coloca estão relacionados ao próprio regime democrático, que estabelece "...a junção entre um demos heterogêneo, dividido por interesses contraditórios e portanto sempre em estado de conflito potencial, e a necessidade, comum a todas as sociedades, de manter um mínimo de unidade entre seus integrantes" (MIGUEL, 2002, p.160).

Howlett (2000) divide a influência da opinião pública nos processos políticos em etapas, que não seguem necessariamente uma linearidade, mas ajudam-nos a identificar alguns atores dessa política, bem como compreender como esse

14 Segundo Miguel (2002), uma das características centrais que definem a mídia é a desigualdade entre emissor e receptores. 
processo não ocorre de forma direta. Sucintamente, as etapas para compreender os efeitos da opinião pública são:

- Construção da agenda: compreender como os problemas chegam à atenção do governo por atores específicos e de que modo surgem na agenda do governo. Atores estatais, partidos políticos, meios de comunicação de massa tomam a frente nesse processo. No entanto, pesquisas de opinião pública, mobilizações de grupos da sociedade civil e até cidadãos individualmente, por meio de conselhos especializados, por exemplo, podem influenciar a construção da agenda. Aqui os meios de comunicação desempenham um papel relevante e ativo, aumentando as percepções públicas, construindo-as e, em alguns casos, influenciando, o teor das políticas: progressistas ou conservadoras, pessoais ou sociais.

A ausência de voz dos adolescentes que cometeram atos infracionais, ou de outros setores como os movimentos sociais, ONG's, etc., que poderiam falar sobre a temática da criminalidade juvenil, é notável nas matérias veiculadas. Ou seja, há ausência de voz na disputa pelas representações do mundo social, o que implica, em não democratizar a esfera política. Tal empreitada, longe de um 'ideal representativo', implicaria em, ao menos, tornar mais equânime o acesso aos meios de difusão das representações do mundo social.

A construção da agenda, portanto, ou a retomada da discussão acerca da redução da maioridade penal, nesses momentos de repercussão pública, implicou em: 1) divulgar amplamente determinada questão em um dado meio de comunicação e 2) influenciar a agenda política pelo conteúdo das notícias através da seleção, ênfase, exclusão e elaboração de um conteúdo - o chamado 'media frame'. (HEAVER, 2007)

Callaghan e Schnell (2001), por exemplo, trataram os frames da mídia nos discursos da elite política no debate sobre o controle das armas nos EUA. Eles citam alguns frames ditos ou implícitos nos discursos, por exemplo: 'armas detêm o crime'; 'armas não matam, mas sim as pessoas que as utilizam'.

Tal relação pode ser feita quando pensamos a questão da maioridade penal. Como demonstramos anteriormente, a repercussão na Revista Veja e no jornal Folha de S.Paulo, em 2003 e 2007, dos crimes envolvendo dois adolescentes mostraram a forte mobilização dos meios de comunicação. Esses tores exerceram um papel relevante, seja no apoio à medida, como fez a revista Veja, seja na ampla divulgação dos fatos pela Folha de S. Paulo e em sua oposição à redução da inimputabilidade penal.

Os atores Folha de S. Paulo e Veja desempenharam papel relevante na construção da agenda, pois, pesquisas de opinião foram realizadas e divulgadas; partidos políticos e autoridades como ministros do STF, dos direitos humanos manifestaram publicamente suas posições em relação à redução da inimputabilidade penal. Atores individuais também influenciaram a retomada da 
tramitação das PEC'S: o pai de Liana, Ary Friedenbach, na época do crime mobilizou campanhas favoráveis à redução da maioridade penal recolhendo assinaturas no parque do Ibirapuera favoráveis à medida.

- Formulação de políticas: o público não é, em geral, representado diretamente na formulação ou nas propostas de políticas públicas, mas exerce efeitos indiretos. A representação da opinião pode ser indireta através de instituições e organizações públicas representativas, ou seja, pelos representantes eleitos, grupos de interesse, administradores governamentais e outros. No entanto, essa representação fica limitada pelos papeis exercidos pelo poder político e pela burocracia no processamento de políticas. Nessa etapa, organizações e instituições públicas são, portanto, os atores principais, ainda que a opinião pública exerça efeitos relevantes. Partidos e deputados tiveram maior influência no debate nesse momento: o PSDB, por exemplo, mobilizou alguns de seus principais líderes (como José Serra e Alckmin), para a defensa da redução da maioridade penal ou do aumento do prazo de internação estabelecido pelo ECA dos atuais 3 anos para 10 anos (projeto que tramita no Senado com grande apoio de diferentes grupos da sociedade civil e com possibilidades de vir a ser aprovado).

O PTB (Partido Trabalhista Brasileiro) tem campanha favorável à medida desde 1995 na Assembleia Legislativa de São Paulo, defendendo a redução da maioridade penal para 14 anos (o que refletiu na proposta apresentada pelo deputado Nelson Marquezelli). O público exerceu efeitos mais indiretos, mas não menos importantes, influenciando tanto a formulação das propostas favoráveis, como seus conteúdos. Pode-se dizer que os meios de comunicação, também exercem influência no modo como divulgam as informações, influenciando o conteúdo da formulação da redução da maioridade penal. Parece crível que ampla repercussão pública do assunto e a mobilização de amplos setores sociais, pelos meios de comunicação, influenciaram os parlamentares a tomarem iniciativas de colocar de novo a proposta na pauta da agenda do Congresso.

- Tomada de decisões: nessa fase do processamento de políticas, a opinião pública exerce menor efeito, pois o número de atores políticos relevantes diminui. Ao menos quando a questão são os plebiscitos e referendos, a tomada de decisões em políticas públicas se concentra fundamentalmente em políticos, juízes e funcionários autorizados a tomar decisões em uma área específica excluindo, desse modo, quase todos os atores não-estatais e os que pertencem a outros ramos do governo. Os líderes políticos têm papel preponderante nos resultados das políticas, ainda que a opinião pública possa criar um 'clima de políticas' por uma demanda específica.

Nessa fase, a opinião pública não exerceu efeitos significativos na Câmara dos Deputados. A tramitação na Comissão de Constituição e Justiça e de Cidadania (CCJC) das PEC'S até os dias atuais, em períodos que não necessariamente 
existiram algum crime de grande repercussão que mobilizasse os meios de comunicação de massa, excluiu quase completamente os atores não-estatais.

Por outro lado, o STF, o Congresso Nacional, os Ministérios, além de ONG'S, institutos, profissionais liberais têm relevância, uma vez que possam vir a contribuir para a aprovação ou não da medida. Em 2001, por exemplo, uma audiência pública organizada pelo Congresso Nacional, Secretaria de Estado dos Direitos Humanos, Ministério da Justiça e pelo CONANDA (Conselho Nacional de Defesa dos Direitos da Criança e do Adolescente) sistematizou argumentos contrários às propostas ${ }^{15}$.

Assim, a não ser que a maioridade penal venha a ser decidida em plebiscito ou referendo ${ }^{16}$, a opinião pública, nessa etapa, tem influenciada a maioridade penal apenas no "clima de políticas". Em 2007, por exemplo, audiências públicas voltaram a acontecer no Congresso Nacional após o ocorrido no Rio de Janeiro. Passemos à etapa da implementação das políticas:

- Implementação de políticas: esse é pouco afetada pela opinião pública; a burocracia especializada constitui os atores centrais nessa fase do processo político devido à dimensão dos recursos politicamente relevantes que ela controla. Embora o executivo possa intervir em uma questão de grande atenção pública, de fato, a burocracia por suas características (lei que a regulamenta; amplo acesso a recursos materiais; controle de habilidades específicas e conhecimento técnico especializado; abrangência de profissionais de diversas áreas que a constitui; acesso privilegiado a informações e a deliberações políticas) sofre pouca influência da opinião pública no que diz respeito à implementação de uma política.

Partindo do que Howlett (op. Cit.) descreveu, pode-se dizer que a opinião pública afeta muito pouco a possível implementação da maioridade penal no Brasil. Conforme vimos nas declarações da Folha de S. Paulo, por exemplo, o atual presidente é contrário à questão, posicionamento demonstrado diversas vezes entre 2003 e 2007.

A posição do executivo é relevante para tensionar como a 'opinião pública' não é uniforme ou desprovida de conflitos na relação mídia e política. O campo político também não absorve esta atenção pública de forma unívoca. Internamente, as instituições políticas possuem divisões de ordem burocrática (posições nas comissões, presidência das casas legislativas, composição do supremo tribunal federal, etc) como também divisões partidárias e ideológicas que conferem diferentes configurações no sistema representativo e na absorção de um tema político na Câmara dos Deputados. Muitas vezes a representação política deforma ou altera o conteúdo da demanda dos representados em função do campo político.

15 Essa audiência deu origem ao livro: A RAZÃO DA IDADE: mitos e verdades. Brasília: MJ/SEDH/DCA, 2001.

16 Existem propostas de deputados do PTB nesse sentido. Luiz Antônio Fleury propôs em 2005 a convocação de um plebiscito sobre a alteração da maioridade penal para dezesseis anos e a alteração da lei de crimes hediondos em 2005 através da proposta PDC (Projeto de Decreto Legislativo) - 1579. 
A construção da agenda e a implementação das políticas são perpassadas também pelas posições políticas dos partidos em função das relações políticas dos representantes.

Ainda que alguns atores estatais como os partidos, as Comissões da Câmara e do Senado votem favoravelmente à redução da maioridade penal, o Executivo já demonstrou que não apóia a medida. É provável que a implementação da redução da inimputabilidade penal não dependa somente deste posicionamento do Executivo, mas se mostre fator relevante no processo decisório. No entanto, tal contexto pode ser relativizado com a possibilidade de realização de plebiscito ou referendo sobre o tema.

Veremos a última etapa do processamento da opinião pública descrito por Howlett:

- Avaliação de políticas: embora a opinião pública tenha efeitos fracos e indiretos nessa etapa do processo político, essa fase é importante por envolver o legislativo como um dos atores centrais na avaliação de políticas. Ou seja, embora o voto seja a mais importante forma de participar dos processos políticos na democracia, ele possibilita uma escolha geral de governo mais do que de políticas específicas. Mesmo quando determinados partidos oferecem um 'pacote' de políticas específicas para uma área das políticas, o sistema eleitoral não permite essa escolha tão específica. Assim, a maioria das avaliações são realizadas por juízes ou funcionários do governo e nas revisões legislativas (que nos interessam aqui diretamente). Nesses casos, os efeitos da atenção pública foram pequenos, já que muitas das avaliações são feitas em comissões específicas, compostas por bancadas partidárias para analisar uma demanda da sociedade civil. A complexidade aumenta na medida em que as comissões podem envolver questões sobre jurisprudências fundamentais (cláusulas pétreas da constituição, por exemplo), posições partidárias e individuais dos deputados, ou ainda benefícios políticos na política pública a ser analisada.

Em relação à avaliação de políticas, a redução da maioridade penal é atravessada por uma questão constitucional fundamental: ser ou não cláusula pétrea (ou seja, ser ou não parte dos direitos e garantias fundamentais da Constituição de 1988).

Embora existam juristas importantes, como Miguel Reale (2001), que não a compreendam como cláusula pétrea, há grupos significativos que dizem o contrário. Para esses, a maioridade penal é cláusula pétrea e, portanto, não se efetivará enquanto política pública, mesmo aprovada na Câmara dos Deputados, no Senado Federal e pelo Executivo. Sobre esse aspecto, diz Dallari:

"A previsão de tratamento jurídico diferente daquele que se aplica aos adultos é um direito dos menores de 18 anos, que são pessoas, indivíduos, 
sujeitos de direitos. De acordo com o artigo 60, $\S 4^{\circ}$, da Constituição, não poderá ser objeto de deliberação proposta de emenda constitucional tendente a abolir garantias individuais" (DALLARI, 2001, p. 25).

Assim, qualquer proposta no sentido de reduzir a maioridade penal significaria a abolição do direito ao tratamento diferenciado dos adolescentes previsto na Constituição, o que é inconstitucional segundo os que vêem a medida como cláusula pétrea.

Vimos que os dois veículos de comunicação influenciaram a opinião pública e a Câmara dos Deputados na retomada da agenda e na formulação de políticas. Claro, mídia e política formam dois campos diferentes, que possuem características próprias e autonomia, e "a influência de um sobre o outro não é absoluta nem livre de resistências; na verdade, trata-se de um processo de mão-dupla." (MIGUEL, 2002, p.167). Pode-se dizer que a mídia, portanto, desempenha forte papel na formação do capital político, e ainda condiciona que determinado candidato ao apresentar uma proposta, como as PEC's, modele sua trajetória política através de sua exposição na mídia. No entanto, não estamos afirmando que ela possui exclusivamente o monopólio de legitimar a produção desse capital político, mais ou menos, exposto na mídia.

A construção da 'opinião pública', através dos dois meios de comunicação aqui analisados afetou, portanto, a construção da agenda mais do que qualquer uma das outras etapas. Também afetou de forma indireta a formulação de políticas, exercendo efeitos importantes e constitutivos do ambiente em que operam os sistemas de políticas.

Quanto à tomada de decisões, ou seja, sobre a possibilidade de tal política ser efetivamente aprovada pelo Parlamento e pelo Executivo, não podemos afirmar a mesma influência. Pois, como demonstramos, a posição atual do Executivo e do partido governista (PT) é contrária à redução da maioridade penal. Vale a ressalva que tal afirmação não é válida no caso de a redução da maioridade penal ser decidida em plebiscito ou referendo.

Em relação à implementação e avaliação de políticas, há menor influência da 'opinião pública'. Ou seja, a implementação deve ser pensada depois que uma política pública foi decidida (o que ainda não ocorreu).

Quanto à avaliação, que é feita por comissões especializadas, penso que há efeitos da repercussão pública de um crime, como nesses casos, mas a decisão passa além do fato ocorrido. Seja pelo período de tramitação de uma proposta na comissão, seja pela formação da comissão (favorável ou não à medida), seja pelos indivíduos que julgam a medida e compõem os cargos das comissões (podem estar mais ou menos sob influência da repercussão pública de um crime, ou serem contra ou a favor à medida, dependendo da posição majoritária do partido ou do governo). 


\section{Considerações finais}

Neste artigo, o modelo de Howlett pôde ser aplicado porque em 2003 e 2007 a atenção pública foi inflada pelos meios de comunicação estudados (eja e Folha de S. Paulo), por líderes partidários e autoridade públicas, que influenciaram a construção da agenda mais do que nas outras etapas, mas também a formulação de políticas através dos efeitos indiretos pelos representantes eleitos, grupos de interesse e outros. Por último, a repercussão pública dos crimes influenciou o sistema pelo menos na criação de um 'clima de políticas' que, por conseguinte, influenciou a tomada de decisões e a retomada (em maior número de propostas) da tramitação na Câmara dos Deputados, nos dois casos analisados.

Tal análise não está relacionada com o elitismo político, que divide a política em 'bastidores', nos quais se tomam as decisões, e o 'palco' frequentado pelo povo (os não-iniciados). Como tentei mostrar, também não se pretende negar os limites representativos da democracia formal e a limitação da participação política popular no processo decisório. Ademais, como assinala Miguel (2002), a distinção entre bastidores e palco deve ser relativizada, pois: (i) a passividade política ou irrefletividade da assim chamada 'massa' não é um dado histórico (ii) se, em alguns casos, pode ser notada tal passividade, é interessante analisarmos como é produzida essa passividade e, além disso, como, em determinados momentos, tal passividade é rompida no processo político, pelos movimentos sociais, por exemplo, sobre uma determinada questão política.

A constante reivindicação de maior punição para os jovens através das propostas de redução da maioridade penal nos aponta a complexidade da relação entre meios de comunicação de massa, criminalidade e legislativo. O interessante, no quadro da segurança pública do regime democrático brasileiro, é analisar como estão conciliadas, de modo contraditório, as garantias legais, os direitos humanos e as violações de direitos dos jovens, principalmente quando envolvem os direitos civis $^{17}$ dos jovens criminosos. Inclusive apontam a inquietante relação entre reivindicação do recrudescimento da legislação para crianças e adolescentes autores de atos infracionais, violência policial, rebeliões em FEBEM's, vitimização de jovens ${ }^{18}$, desigualdade de direitos, expansão do crime organizado e da segurança privada entre outras questões que envolvem a criminalidade juvenil no Brasil.

17 Entendemos as dimensões política, civil e social da cidadania na clássica distinção de Marshall (1965), no qual os direitos civis são os direitos necessários para a liberdade individual; igualdade perante a lei e os direitos civis em geral; os direitos políticos referem-se ao direito de participar de organizações políticas, votar e candidatar-se a cargos políticos; e os direitos sociais são os relacionados ao estado do bem-estar social. Teresa Caldeira (2000) explora bem essa questão para o Brasil.

18 Segundo o relatório da Unesco: Mapa da Violência IV 2004 (1993/2002), houve um crescimento da taxa de mortalidade entre os jovens, principalmente na taxa de homicídios e acidentes de transporte. 0 número de homicídios entre 15 e 24 anos subiu de 30 em 100.000, em 1980, para 54,5 em 100.000, 
A formação de julgamentos e atitudes dos indivíduos, que inclui em nossa análise os deputados, está relacionada com determinados casos ou associações trazidas à mente pela grande mídia. Tal premissa baseia-se na ideia de priming, como já foi dito, pois as pessoas processam as informações mais acessíveis. Nesse sentido, a mídia de massa pode formar as considerações, julgamentos e perspectivas com as quais as pessoas interpretam determinados assuntos.

Nas sociedades contemporâneas, a mídia é um dos principais locais em que estão expostas as diversas representações do mundo social, em conjunto com diversos grupos e interesses presentes na sociedade. "As vozes que se fazem ouvir na mídia são representantes das vozes da sociedade, mas esta representação possui um viés" (MIGUEL, 2002, p.163).

Por conseguinte, o resultado de tal relação é que os meios de comunicação reproduzem mal a diversidade do tecido social, o que acarreta problemas e tensões significativas no exercício do regime democrático, como nos dois casos cobertos pela Revista Veja. O processo de estigmatização dos jovens que cometeram os crimes citados é facilmente percebido nas matérias veiculadas. Há, sobretudo, nos dois meios de comunicação analisados "a ausência de voz na disputa pelas representações do mundo social, que se trava nos meios de comunicação" (idem).

Ou seja, os meios de comunicação de massa, através do teor das notícias (no caso da Veja) ou através do número de reportagens sobre o tema (Folha de São Paulo) formam um quadro (frame) no qual a perspectiva, o específico 'enquadramento dos crimes' de uma perspectiva (jovens como algozes e que devem ser violentamente punidos) é fato importante para a retomada na sociedade civil do debate sobre a redução da maioridade penal. No entanto, tal debate assume determinados padrões, em contextos de uso específicos e, isso se reflete, em maior ou menor grau, na tramitação da Câmara dos Deputados.

Os infratores estão afastados dos processos de criação da informação midiática. Quando as pesquisas apontam o aumento do apoio da população à diminuição da maioridade penal, essas pesquisas estão deixando de lado e negligenciando as "vozes" dos infratores ou de outros setores que possam ser contrários a redução, massificando uma posição parcial e tentando transformá-la em "geral". Essa luta entre campo político e campo midiático é permanente e está ligada à construção social da opinião pública acerca de uma temática.

O quadro (frame ${ }^{19}$ ), para Goffman, é um artifício que seleciona, segundo as intenções e as perspectivas de um sujeito individual ou coletivo, aquilo que

em 2002, enquanto entre os grupos da população o índice permaneceu estável. Disponível em: $<$ http://www.unesco.org.br>.

19 Segundo Nunes (2007), "O conceito de frame ainda não encontra uma tradução consensual na sociologia brasileira, apesar de o termo "enquadre" já estar fixado no Brasil como tradução de frame na psicologia (cf. Ribeiro e Garcez, 2002, p. 107). Prefiro empregar o termo "quadro", que evoca a proximidade com a técnica da fotografia e do cinema (enquadramento, framing, quadro da película, 
percebemos. Há sempre uma forma de organizar a percepção e a experiência, que pode se convencionalizar, assumindo determinados padrões, mas que se atualiza, ou se efetiva, a cada instância em que são realizadas:

“Existe sempre uma ação subjacente ao quadro e que não é definida ou estruturada apenas pelo seu objeto, mas também por técnicas que são socialmente reconhecidas, ou seja, por um contexto de uso" (NUNES, 2007, p.258).

Acreditamos, portanto, que os meios de comunicação divulgam os crimes de grande repercussão pública e reestabelecem, nesses períodos específicos, o debate sobre a maioridade penal através da seleção de determinados aspectos sobre o tema. Tal seleção de enquadramento, pela mídia, forma o tipo de entendimento e organização da experiência de alguns indivíduos a respeito da questão da redução da maioridade penal, colocando o tema novamente na agenda política.

Nessa perspectiva, Bourdieu (1997) já assinalou que os dois campos, político e jornalístico estão sob influência da sanção do mercado e do plebiscito. Possuem assim influências recíprocas:

"Daí decorre que a influência do campo jornalístico reforça as tendências
dos agentes comprometidos com o campo político a submeter-se à pressão
das expectativas e das exigências da maioria, por vezes passionais e
irrefletidas, e frequentemente constituídas como reivindicações
mobilizadoras pela expressão que recebem na imprensa" (BOURDIEU,
1997, p.114-115).

Através dos meios de comunicação, ocorre a influência da 'opinião pública', ou seja, alguns indivíduos ou, no caso, os parlamentares organizam a sua percepção (seus esquemas interpretativos) sobre uma temática, influenciados pela repercussão pública de crimes, reivindicando em seguida determinada política pública - a redução da maioridade penal.

Nesse contexto de busca cada vez maior por segurança, as instituições de participação e consultas populares, referendos, eleições podem ser meios nos quais os cidadãos exercem controle sobre o Estado. No entanto, esses processos de consultas populares podem ter como consequência o que Tocqueville já dizia há dois séculos: mecanismos nos quais alegremente os cidadãos se aprisionam mais (GINSBERG, 1986, p.30-31).

fotograma) e também, no vernáculo, incorpora o sentido de "estrutura","moldura", "esqueleto"que o termo apresenta na língua inglesa. Além disso, "quadro" significa "referência", "perspectiva", sentidos fundamentais na sociologia interpretativa e, principalmente, nas escolas do interacionismo simbólico e da etnometodologia, tão caras a Goffman" (NUNES, 2007, p. 258) 
Essa perspectiva, no entanto, não inviabiliza o reconhecimento da receptividade das demandas de opinião pública e da sociedade civil pelos governos como uma das grandes virtudes da vida política ocidental e dos processos políticos. A questão é que, além de favorecer os interesses dos cidadãos, a 'opinião pública' em muitos casos pode favorecer o interesse do Estado de domesticá-la, regulá-la, delimitar seu impacto e subordiná-la a seus propósitos. Utilizando-se dela, o Estado pode fortalecer-se ao invés do fortalecimento da sociedade civil.

Assim, uma possível aprovação da redução da maioridade penal atua como uma forma de o Estado servir a si mesmo e enfraquecer a sociedade civil no Brasil, prendendo cada vez mais os jovens e aumentando a desigualdade de direitos a que muitos jovens já estão submetidos no Brasil ${ }^{20}$.

Segundo a pesquisa CNI/Ibope, do dia 27 de março de 2008, a redução da maioria penal é apoiada por $83 \%$ da população, que defendem a redução de 18 para 16 anos. Enquete realizada em 2009 no site do Senado Federal ${ }^{21}$ sobre a medida apontava que 29,85\% concordavam com a redução para 16 anos; 44,18\% concordavam com a redução para menos de 16 anos e 25,95\% não concordavam.

A contradição, portanto, reside em, de um lado, a entrada da voz pública nos mecanismos do Estado e, de outro, a domesticação dessa opinião a serviço do interesse do próprio Estado. No caso da redução da maioridade penal no Brasil, a contradição aparece em prender mais os jovens não privilegiados atendendo à reivindicação de grande parte da sociedade e grupos favoráveis à medida ao invés da implementação efetiva do ECA, buscando a ampliação e efetivação dos direitos civis e sociais dos jovens e ainda a garantia da não violação dos mesmos.

Buscamos apontar neste artigo algumas possíveis relações entre meios de comunicação e processos políticos nos quais o processo de formação de políticas

\begin{abstract}
20 Segundo o Mapeamento Nacional das Medidas Socioeducativas em Meio Aberto ILANUD/SEDH (2007), a partir das informações fornecidas por 608 varas competentes pela execução de medidas socioeducativas, distribuídas por 607 municípios de 25 estados e mais o Distrito Federal. Existem 54.785 adolescentes cumprindo medidas socioeducativas no país, sendo 33.597 das medidas em meio aberto; 10.594 em meio fechado; 4.038 em semiliberdade e 6.556 internados. Entre os atos infracionais, o roubo apresenta 25,4\%; furto, 16,9\%; tráfico de drogas, $8,3 \%$; porte ilegal de arma, 5,1\%; lesão corporal, 4,1\%; roubo tentado, 3,6\%; posse de drogas, 2,7\%; homicídio, 2,3\%; homicídio tentado, 1,3\%; furto tentado, 1,9\%; ameaça, 1,8\%; dano, 1,8\%; outros atos infracionais, $7,1 \%$. Os crimes contra a pessoa totalizam 13,6\% sendo: 4,3\%, lesão corporal; homicídio, 4,1\%; ameaça e outros, 1,9\%; crime contra os costumes, 1,7\%; Outros crimes contra a pessoa, 0,8\%; lesão corporal, 0,5\%; homicídios e outros, $0,4 \%$; crimes contra o patrimônio, $62,8 \%$ e relacionados ao tráfico e uso de drogas, $10,3 \%$. Quanto à idade: até 11 anos, 0,2\%; 12 a 15, 17,6\%; 16 a 17, 44\%; 18 a 21, 34,5\%.

Quanto à escolaridade: $3,4 \%$ têm menos que o ensino fundamental; $51,8 \%$ Ensino fundamental; $6,5 \%$ Ensino Médio e sem informação 37,8\% (Dados excluem o Rio Grande do Sul). Os dados do Rio Grande do Sul apontam $58,9 \%$ crimes contra o patrimônio e $21,7 \%$ contra a pessoa, sendo $1,7 \%$ homicídios e 9,4\% de lesão corporal. Agradeço ao ILANUD, em especial a Paula Miraglia, Karyna Sposato, Aline Yamamoto e Marina Menezes pela disponibilização dos dados.

21 Resultado parcial com acesso em 26/06/2009.
\end{abstract}


públicas pode, em certos casos, demandar formas de governo específicas. A tarefa nos coloca o desafio de analisar como o desenho institucional se relaciona com a capacidade que a democracia pode ter de intervir em uma determinada demanda da sociedade civil. E, até mesmo, em quais etapas a repercussão pública de um fato específico teve maior ou menor capacidade de influenciar à (re) tomada de discussão acerca de uma política pública, no caso, a redução da maioridade penal.

\section{Referências Bibliográficas}

ALVAREZ, M. C. "Menoridade e delinquência: uma analise do discurso jurídico e institucional da assistência e proteção aos menores no Brasil". Cadernos da FFC, Marília, v.6, n² 2, 1997.

BOURDIEU, P. Sobre a Televisão. Rio de Janeiro: Ed. Jorge Zahar, 1997.

CALDEIRA, T. P. do R. Cidade de muros: crime, segregação e cidadania em São Paulo. São Paulo: Edusp, 2000.

CALLAGHAN, K. e SCHNELL, F. "Assessing the democratic debate: how the news media frame elite policy discourse". Political Communication, v.18, 2001.

CERVI, E.U. Opinião Pública e Política no Brasil: o que o brasileiro pensa sobre política e porque isso interessa à democracia. Tese de Doutorado em Ciência Política, Instituto Universitário de Pesquisas do Rio de Janeiro, Rio de Janeiro, 2006.

CHAMPAGNE, P. Formar a opinião. São Paulo: Vozes, 1998.

DALLARI, D. de A. A razão para manter a maioridade penal aos 18 anos. In: BULHÕES, A. N. A. (et al). A Razão da ldade: Mitos e Verdades. Brasília: MJ/SEDH/DCA, 2001. 
DOWNS, A. "Up and Down wtih Ecology - the 'Issue-Attention Cycle'." The Public Interest, v.28, 1972.

GINSBERG, B. The Captive Public. How Mass opinion promotes state power. New York: Basic Books, 1986.

GOFFMAN, E. Frame analysis. New York: Harper \& Row, 1974.

. A representação do eu na vida cotidiana. Petrópolis: Ed. Vozes, 1996.

HABER, C. D. A eficácia da Lei penal: análise a partir da legislação penal de emergência (o exemplo do Regime Disciplinar Diferenciado). Dissertação de mestrado em direito, Faculdade de Direito da Universidade de São Paulo, 2007.

HABERMAS, J. Mudança Estrutural da Esfera Pública. Rio de Janeiro: Tempo Brasileiro, 2003.

HOWLETT, M. "A dialética da Opinião Pública: efeitos recíprocos da política pública e da opinião pública em sociedades democráticas contemporâneas". Opinião Pública, Campinas, v.6, $\mathrm{n}^{\circ}$ 2, 2000.

ILANUD/Secretaria Especial dos Direitos Humanos. Mapeamento Nacional das Medidas Sócio Educativas em Meio Aberto. Relatório Final. v. 1 e 2, dez. 2007.

LEAL, C.B. A redução da idade de responsabilidade penal como instrumento de vitimização de adolescentes infratores. In: LEAL, C.B; JÚNIOR, H. P (orgs.). Idade de responsabilidade penal: a falácia das propostas reducionistas. Belo Horizonte: Editora Del Rey, 2003.

MARSHALL.T. Cidadania e Classe Social. Rio de Janeiro: Editora Zahar, 1967.

MIGUEL, L. F. "Os meios de comunicação e a prática política". Lua Nova Revista de Cultura e Política, $\mathrm{n}^{\circ}$ 55-56, 2002.

MORELLI, A.J. "A inimputabilidade e a impunidade em São Paulo". Revista Brasileira de História, São Paulo, v.19, n 37, set.1999. 
NUNES, J.H. "A sociolinguística de Goffman e a comunicação mediada". Tempo Social - Revista de Sociologia da USP, v.19, n², 2007.

PEREIRA, I. "Redução da idade de responsabilidade penal de adolescentes". Revista do ILANUD: Adolescentes em Conflito com a Lei, n 14, 2001.

PIERUCCI, A. F. Ciladas da Diferença. São Paulo: Editora 34, 1999.

RIBEIRO, B. T. e GARCEZ, P. M. (orgs.). Sociolinguística interacional. São Paulo: Loyola, 2002.

RODRIGUES , L. M . Partidos, ideologia e composição social. São Paulo: EdUsp, 2002.

SARAIVA, J.B.C. "A idade e as razões: não ao rebaixamento da imputabilidade penal". In: SOUZA, L. A. F. Criminologia, direito penal e justiça criminal no Brasil: uma revisão da pesquisa recente. BIB. Revista Brasileira de Informação Bibliográfica em Ciências Sociais, São Paulo, v. 59, 2005.

SCHEUfELE, D.A e TEWKSBURY, D. "Framing, Agenda Setting, and Priming: the evolution of three media effects models". Journal of Communication , v.57, International Communication Association, 2007.

TEIXEIRA, A. Do sujeito de Direito ao Estado de Exceção: o percurso contemporâneo do sistema penitenciário brasileiro. Dissertação de Mestrado. Departamento de Sociologia. Universidade de São Paulo, 2006.

TERRA, E.C. A idade penal mínima como cláusula pétrea. In: BULHÕES, A. N. A et al. A Razão da Idade: Mitos e Verdades. Brasília: MJ/SEDH/DCA, 2001.

TAVARES de ALMEIDA, M. H. "Mais do que meros rótulos". Artigo publicado no Jornal Folha de S. Paulo, no dia 25/02/2006, na coluna Opinião, p. A. 3.

VOLPI, M. (org). Adolescentes privados de liberdade: A Normativa Nacional e Internacional \& Reflexões acerca da responsabilidade penal. São Paulo: Cortez, 1998. 
WEBER, M. "Sociologia da Imprensa: um programa de pesquisa". Lua Nova Revista de Cultura e Política, $n^{\circ}$ 55-56, 2002.

WEAVER, D. "Thoughts on Agenda Setting, Framing, and Priming". Journal of Communication, v.57, International Communication Association, 2007.

Marcelo da Silveira Campos - celo_campos@hotmail.com

Recebido para publicação em outubro de 2008.

Aprovado para publicação em abril de 2009. 